\title{
Involvement of dopamine receptors in diethylpropion-induced conditioning place preference
}

C.S. Planeta ${ }^{1}$ and R. DeLucia ${ }^{2}$

\section{Correspondence \\ C.S. Planeta \\ Departamento de Princípios Ativos Naturais e Toxicologia, FCF, UNESP Rodovia Araraquara-Jaú, $\mathrm{km} 01$ 14801-902 Araraquara, SP Brasil \\ Fax: 55 (016) 222-0073 \\ E-mail:cplaneta@fcfar.unesp.br \\ Research supported by CNPq. Publication supported by FAPESP. ....................}

Received July 14, 1997 Accepted January 19, 1998

\author{
1Departamento de Princípios Ativos Naturais e Toxicologia, Faculdade de Ciências \\ Farmacêuticas, Universidade Estadual Paulista, Araraquara, SP, Brasil \\ ²Departamento de Farmacologia, Instituto de Ciências Biomédicas, \\ Universidade de São Paulo, São Paulo, SP, Brasil
}

\section{Abstract}

Diethylpropion (DEP) is an amphetamine-like agent used as an anorectic drug. Abuse of DEP has been reported and some restrictions of its use have been recently imposed. The conditioning place preference (CPP) paradigm was used to evaluate the reinforcing properties of DEP in adult male Wistar rats. After initial preferences were determined, animals weighing 250-300 g ( $\mathrm{N}=7$ per group) were conditioned with DEP $(10,15$ or $20 \mathrm{mg} / \mathrm{kg})$. Only the dose of $15 \mathrm{mg} / \mathrm{kg}$ produced a significant place preference $(358 \pm 39$ vs $565 \pm 48 \mathrm{~s})$. Pretreatment with the D1 antagonist SCH $23390(0.05 \mathrm{mg} / \mathrm{kg}, \mathrm{sc}) 10$ min before DEP (15 mg/kg, ip) blocked DEP-induced CPP (418 \pm 37 vs $389 \pm 31 \mathrm{~s})$ while haloperidol $(0.5 \mathrm{mg} / \mathrm{kg}$, ip $)$, a D2 antagonist, 15 min before DEP was ineffective in modifying place conditioning produced by DEP $(385 \pm 36$ vs $536 \pm 41 \mathrm{~s})$. These results suggest that dopamine D1 receptors mediate the reinforcing effect of DEP.

\section{Key words}

- Diethylpropion

- Conditioning place preference

- Reinforcing effect

- Dopamine receptors
Diethylpropion (DEP) is an amphetaminelike agent widely marketed in Brazil as an anorectic drug. Abuse of DEP has been reported among students (1) and some restrictions of its use have been recently imposed. DEP increases locomotor activity and produces stereotyped behavior in rats (2). These effects seem to be mediated by the action of DEP on dopamine-containing neurons. Like other amphetamine-like drugs, DEP acts on dopaminergic presynaptic terminals producing an increase in dopamine release (3).

It has been demonstrated that DEP induces self-administration in rats $(4,5)$, suggesting that it can act as a positive reinforcer. This observation indicates that DEP can be addictive in humans since most abused drugs act as positive reinforcers in conditioning paradigms (6). The conditioning place preference (CPP) is a method extensively used to assess the reinforcing actions of drugs. It has been demonstrated that most substances abused by humans produce CPP. For example, CPP has been demonstrated for cocaine, amphetamine, fencamfamine, morphine, nicotine and ethanol (7-11).

Numerous findings from behavioral and pharmacological research suggest that dopaminergic function plays an important role in the reinforcing effects of drugs $(5,6,12)$. Most studies have been conducted on the mesolimbic dopaminergic system since the increase of dopamine concentration in the nucleus accumbens appears to be a common 
property of abused drugs such as cocaine, amphetamine, nicotine, ethanol and morphine $(13,14)$. Dopamine receptors in the nucleus accumbens seem to mediate the reinforcing effect of psychostimulants (15). However, the relative role of dopamine receptor subtypes is still controversial, with reports that SCH 23390 and haloperidol, D1 and D2 antagonists, respectively, blocked amphetamine-induced CPP $(16,17)$, while fencamfamine-induced CPP is blocked by D1 but not D2 antagonists (11).

The present experiments evaluate the reinforcing properties of DEP using the CPP paradigm and assess the role of D1 and D2 receptors in the reinforcing effect of DEP.

Adult male Wistar rats weighing 250 to $300 \mathrm{~g}$ were maintained at $22 \pm 2^{\circ} \mathrm{C}$ on a 12 $\mathrm{h}$ light/12-h dark cycle, with lights on at 7:00 $\mathrm{h}$, for 9 weeks before the beginning of the experiments. Food and water were freely available except during the behavior observation periods, when they were withdrawn. Behavioral tests were conducted during the light period.

The apparatus used for the conditioning place preference procedure consisted of a rectangular $90-\mathrm{cm}$ long x $15-\mathrm{cm}$ wide x $22-$ $\mathrm{cm}$ high shuttle box divided into two equalsized compartments by a guillotine door. One compartment had white walls and a grid floor, and the other black walls and a smooth floor.

The experimental procedure consisted of

Figure 1 - Time (s) spent in the drug-paired compartment during the preconditioning phase and after conditioning with DEP (10, 15 or $20 \mathrm{mg} / \mathrm{kg}$ ). Histograms represent the mean \pm SEM of rats $(\mathrm{N}=7)$ observed for $15 \mathrm{~min}$ in the shuttle box. ${ }^{*} \mathrm{P}<0.05$ pre- $v s$ postconditioning (Newman Keuls test). SAL, Saline.

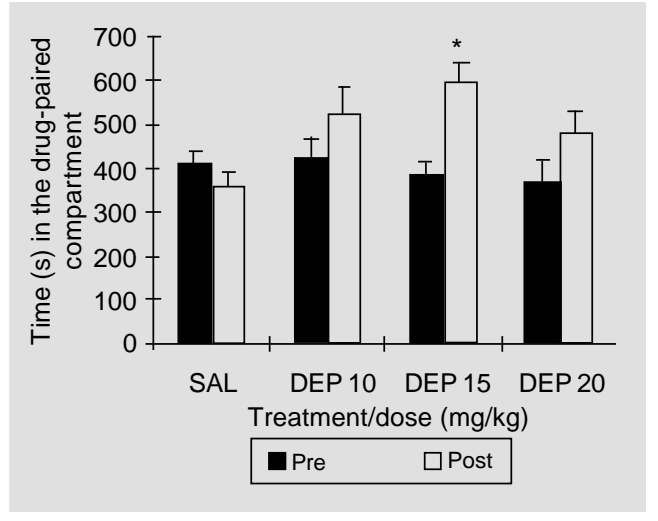

three phases: 1) preconditioning - in this phase animals were placed in one compartment of the shuttle box (initial compartment) for 3 consecutive days and each rat was allowed to explore the two compartments for $15 \mathrm{~min}$. The time spent in each compartment was recorded on the third day. 2) Conditioning phase - animals were injected with DEP or saline on alternate days for 6 consecutive days and confined in the white or black compartment for $30 \mathrm{~min}$. Control groups received saline in both compartments. 3) Postconditioning (test) - on the seventh day the doors were opened and the rats placed in the initial compartment and allowed to freely move inside the apparatus. The time spent in each compartment was recorded for $15 \mathrm{~min}$ in a drug-free situation.

To assess the reinforcing properties of DEP, animals were randomly assigned to groups of seven rats each and injected intraperitoneally (ip) with DEP $(10,15$ and 20 $\mathrm{mg} / \mathrm{kg}$ ). To evaluate the participation of dopamine receptor subtypes in DEP-induced $\mathrm{CPP}$, separate groups of rats were pretreated with either saline, SCH $23390(0.05 \mathrm{mg} / \mathrm{kg}$, $s c)$ or haloperidol $(0.5 \mathrm{mg} / \mathrm{kg}$, ip $)$ before DEP injection in the conditioning sessions. The interval between antagonist and DEP administration was $10 \mathrm{~min}$ for SCH 23390 and $15 \mathrm{~min}$ for haloperidol. Two additional groups were included to determine the effects of the antagonists alone on CPP. Thus, on drug-pairing days saline, $\mathrm{SCH} 23390$ and haloperidol were injected before saline and before the conditioning sessions. All drugs were dissolved in saline.

Data from the CPP experiments were analyzed by two-way ANOVA with repeated measures on one factor. Time spent in the drug-paired compartment in the pre- and postconditioning phase served as the dependent variable with repeated measures. Drug treatment groups served as the independent variable.

Figure 1 shows the mean time $( \pm$ SEM) spent in the drug-paired compartment during 
the pre- and postconditioning phases for animals treated with DEP $(10,15$ and $20 \mathrm{mg} / \mathrm{kg}$, ip). Two-way ANOVA (phase and group factors) with repeated measures on one factor (phase) revelead a significant interaction between phase and dose, $\mathrm{F}(3,24)=8.99$, $\mathrm{P}<0.01$. Thus, the phase factor could be analyzed independently for each treatment group. Comparing the post- to the preconditioning phase, the time spent in the drugpaired compartment was significantly higher only for the group injected with $15 \mathrm{mg} / \mathrm{kg}$ of $\operatorname{DEP}(\mathrm{F}(1,24)=6.08, \mathrm{P}<0.01)$. Control groups showed a decrease in time spent in the white compartment, which, however, was not significant $(\mathrm{F}(1,24)=1.38$, NS $)$.

Figure 2 summarizes the participation of dopamine receptors in DEP-induced CPP. As observed above, two-way ANOVA (phase and group factors) with one repeated measure on one factor (phase) revealed a significant interaction between phase and treatment group, i.e., $\mathrm{F}(3,24)=42.04, \mathrm{P}<0.01$, for $\mathrm{SCH} 23390$, and $\mathrm{F}(3,24)=66.94, \mathrm{P}<0.01$, for haloperidol. When directly tested for place conditioning SCH 23390 did not modify the time spent in the drug-paired compartment $(\mathrm{F}(1,24)=0.67$, NS). As observed before, DEP $(15 \mathrm{mg} / \mathrm{kg})$ significantly induced place conditioning $(\mathrm{F}(1,24)=7.52$, $\mathrm{P}<0.01)$. Pretreatment with $\mathrm{SCH} 23390$ blocked DEP-induced place conditioning $(\mathrm{F}(1,24)=0.80$, NS $)$. Haloperidol plus saline did not change place preference after conditioning trials $(\mathrm{F}(1,24)=0.51, \mathrm{NS})$, whereas both the saline plus DEP $(F(1,24)=$ $6.25, \mathrm{P}<0.01)$ and haloperidol plus DEP $(\mathrm{F}(1,24)=6.57, \mathrm{P}<0.01)$ groups showed a significant increase in the time spent in the drug-paired compartment.

The present study showed that DEP (15 $\mathrm{mg} / \mathrm{kg}$ ) can produce significant place preference in rats. This observation confirms previous reports $(4,5)$ suggesting that DEP may act as a positive reinforcer.

It has been proposed that stimulant and opioid drugs exert their reinforcing effects

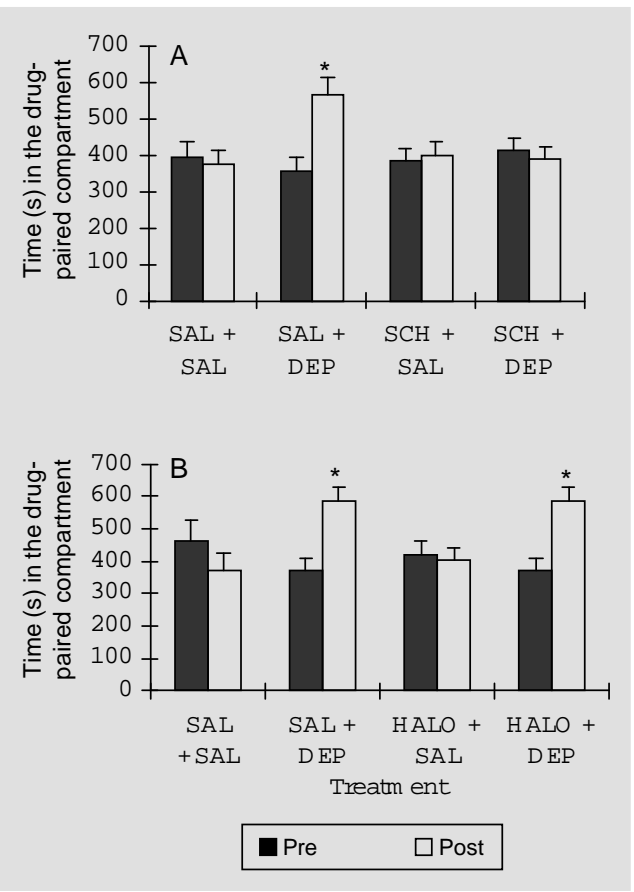

Figure 2 - Effect of pretreatment with the antagonists SCH 23390 $(\mathrm{SCH})(\mathrm{A})$ and haloperidol (HALO) (B) on DEP-induced conditioning place preference. Histograms represent the mean \pm SEM of rats $(\mathrm{N}=7)$ observed in the shuttle box for $15 \mathrm{~min}$ ${ }^{*} \mathrm{P}<0.05$ pre- vs postconditioning (Newman Keuls test). SAL, Saline. by acting on psychomotor activity $(5,6,12$, 18). Thus, to evaluate the involvement of the dopamine dopaminergic mesocorticolimbic system that also mediates receptor subtypes in DEP-induced CPP, animals were pretreated with SCH 23390 or haloperidol, D1 and D2 antagonists, respectively, at doses that block locomotor activity (11). Considering the separate effect of the antagonists, no changes in place preference were observed, suggesting that SCH 23390 and haloperidol are neutral reinforcers in CPP paradigms. The observation that $\mathrm{SCH} 23390$ blocked DEP-induced CPP suggests that the reinforcing effect of DEP depends on the activation of dopamine D1 receptors. Results similar to those obtained with SCH 23390 were found for other addictive drugs such as amphetamine, morphine, nicotine, fencamfamine and diazepam $(7,11,19)$. Our results show that haloperidol did not prevent the acquisition of place preference induced by DEP. In fact, haloperidol and other D2 antagonists such as pimozide and metoclopramide were ineffective in modifying the reinforcing effect of stimulants such as meth- 
ylphenidate, nomifensine or fencamfamine $(11,17,20)$.

In conclusion, our data suggest that DEP- induced CPP and consequently its reinforcing effect are mediated by D1 dopamine receptors.

\section{References}

1. DeLucia R \& Planeta CS (1989). Padrões de uso de psicostimulantes e energizantes por universitários: análise do período 1983-1988. Revista Brasileira de Psiquiatria-APAL, 11:111-113.

2. Safta L, Cuparencu B, Sirbu A \& Secareaneanu AL (1976). Experimental observations on the effect of amphepramone on the behavior, locomotion, penterazol seizures and electroencephalogram. Psychopharmacology, 50: 165-169.

3. Samanin R \& Garrattini S (1993). Neurochemical mechanism of action of anoretic drugs. Pharmacology and Toxicology, 73: 63-68.

4. Griffiths RR, Brady JV \& Snell JD (1978). Progressive ratio performance maintained by drug infusions: comparison of cocaine, diethylpropion, chlorphentermine, and fenfluramine. Psychopharmacology, 56: 5-13.

5. Koob GF (1995). Animal models of drug addiction. In: Bloom FE \& Kupper DJ (Editors), Psychopharmacology: The Fourth Generation of Progress. Raven Press, New York, 759-772.

6. Self DW \& Nestler EJ (1995). Molecular mechanisms of drug reinforcement and addiction. Annual Review of Neuroscience, 18: 463-495.

7. Acquas E, Carboni E, Leone $P$ \& Di Chiara $G$ (1989). SCH23390 blocks drug-conditioned place-preference and place aver- sion: Anhedonia (lack of reward) or apathy (lack of motivation) after dopamine-receptor blockade? Psychopharmacology, 99: 151-155.

8. Shipperberg TS, Emmett-Oglesby MW \& Herz A (1989). Morphine induced place conditioning is not confounded by druginduced alterations in locomotor activity. Pharmacology, Biochemistry and Behavior, 32: 129-132.

9. Bozarth MA (1990). Evidence for the rewarding effects of ethanol using the conditioning place preference method. Pharmacology, Biochemistry and Behavior, 35: 485-487.

10. Hembey SE, Jones GH, Justice JB \& Neill DB (1992). Conditioned locomotor activity but not conditioned place preference following intra-accumbens infusions of cocaine. Psychopharmacology, 106: 330-336.

11. Planeta CS, Aizenstein ML \& DeLucia R (1995). Reinforcing properties of fencamfamine: involvement of dopamine and opioid receptors. Pharmacology, Biochemistry and Behavior, 50: 35-40.

12. Koob GF (1992). Drugs of abuse: anatomy, pharmacology and function of reward pathways. Trends in Pharmacological Sciences, 13: 177-184.

13. Di Chiara G \& Imperato A (1986). Drugs abused by humans preferentially increase synaptic dopamine concentrations in the mesolimbic system of freely moving rats.
Proceedings of the National Academy of Sciences, USA, 85: 5274-5278.

14. Pontiere FE, Tanda G, Orzi F \& Di Chiara G (1996). Effects of nicotine on the nucleus accumbens and similarity to those of addictive drugs. Nature, 382: 255-257.

15. Self DW \& Stein L (1992). Receptor subtypes in opioid and stimulant reward. Pharmacology and Toxicology, 70: 87-94.

16. Hoffman DC \& Beninger RJ (1989). The effects of selective dopamine D1 or D2 receptor antagonists on the establishment of agonist-induced place conditioning in rats. Pharmacology, Biochemistry and Behavior, 33: 273-279.

17. Mithani S, Martin-Iverson MT, Phillips AG \& Fibiger H (1986). The effects of haloperidol on amphetamine- and methylphenidate-induced conditioned place preferences and locomotor activity. Psychopharmacology, 90: 247-252.

18. Wise R \& Bozarth MA (1987). A psychomotor stimulant theory of addiction. Psychological Review, 94: 469-492.

19. Leone $P \&$ Di Chiara G (1987). Blockade of D1 receptor by $\mathrm{SCH} 23390$ antagonizes morphine- and amphetamine-induced place preference conditioning. European Journal of Pharmacology, 135: 251-254.

20. Martin-Iverson MT, Ortmann R \& Fibiger $\mathrm{HC}$ (1985). Place conditioning with methylphenidate and nominfensine. Brain Research, 332: 59-67. 